\title{
CAMPUR TANGAN ASING DI INDONESIA: CRISIS MANAGEMENT INITIATIVE DALAM PENYELESAIAN KONFLIK ACEH (2005-2012)
}

\author{
Eka Auliana Pratiwi \\ Guru Sejarah di Kota Bandung \\ dindha0309@gmail.com
}

Abstract: $\quad$ This article examines the role of "Crisis Management Initiative in Conflict Resolution between the Free Aceh Movement and the Indonesian Government (2005-2012)". As the military approach failed to end conflict in Aceh, the government used a new way of dialogue and third party's involvement as mediators. Under the administration of President Susilo Bambang Yudhoyono (2004-2009) a Non-government organization based in Finland, "Crisis Management Initatiative" was assigned as a part of institutional reform in resolving the conflict. This paper will assess the question of "how was the Role of Crisis Management Initiative in the Conflict Resolution between the Free Aceh Movement (GAM) and the Indonesian Government 2005-2012?". This research will analyze the impact of GAM in Aceh conflict, the reason of CMI's selection as a mediator and the peace process mediated by CMI, and to find out the impact of negotiations for the Aceh people. This research uses historical method which consists of heuristic, criticizing and interpreting the sources as well as historical writing. The results of this research are (1) GAM was formed as a result of Acehnese disappointment towards Indonesian government policy; (2) CMI was a NGO which focuses in conflict resolution; (3) Tsunami have impacted peace process; (5) the peace process was held in five rounds; (4) CMI succeeded to unite both side's aspirations.

Abstrak: $\quad$ Tulisan ini memuat peranan Crisis Management Initiative dalam Penyelesaian Konflik antara Gerakan Aceh Merdeka dengan Pemerintah Indonesia (2005-2012)". Setelah pemerintah Indonesia menggunakan pendekatan militer untuk menyelesaikan konflik yang terjadi di Aceh namun menemui jalan buntu, maka pemerintah Indonesia menggunakan pendekatan baru dengan menggunakan pendekatan dialog dan menghadirkan pihak ketiga sebagai mediator. Pada masa pemerintahan Presiden Susilo Bambang Yudhoyono (2004- 2009) terdapat perubahan lembaga dalam penyelesaian konflik Aceh, yakni mempercayakan NGO asal Finlandia yaitu "Crisis Management Initatiative" sebagai mediator dalam penyelesaian konflik Aceh. Masalah utama yang dibahas dalam skripsi ini adalah "Bagaimana Peranan Crisis Management Initiative dalam Penyelesaian Konflik antara Gerakan Aceh Merdeka dengan Pemerintah Indonesia 2005-2012?”. Metode penelitian yang digunakan adalah metode historis yaitu meliputi pengumpulan sumber, kritik sumber, interpretasi dan historiografi. Hasil dari penelitian ini adalah (1) GAM terbentuk karena adanya kekecewaan masyarakat Aceh terhadap kebijakan Pemerintah Indonesia , (2) CMI merupakan NGO yang bergerak di bidang resolusi konflik, (3) Musibah tsunami berpengaruh terhadap proses perdamaian, (4) proses perdamaian dilakukan sebanyak lima putaran, (4) CMI berhasil menyatukan keinginan kedua belah pihak.

Kata Kunci: $\quad$ Gerakan Aceh Merdeka, Konflik,Crisis Management Initiative, Pemerintah Indonesia.

\section{PENDAHULUAN}

Babak baru dalam perjalanan politik Indonesia pasca merdeka menuai berbagai persoalan, salah satu hal yang sangat mengganggu stabilitas negara adalah adanya gerakangerakan separatis. Gerakan-gerakan ini muncul dikarenakan adanya ketidakselarasan keinginan antara rakyat di suatu daerah dengan pemerintah pusat. Melihat fenomena ini tentunya pemerintah pusat perlu melakukan upaya-upaya untuk mengatasi gerakan-gerakan yang dianggap sebagai penyebab ketidakstabilan nasional.

Gerakan separatis dapat diartikan sebagai gerakan untuk memisahkan diri dari sebuah satu kesatuan yang sering kali menyebabkan konflik dengan konsekuensi merugikan semua pihak yang terlibat. Salah satu gerakan yang menyita perhatian banyak pihak baik nasional maupun internasional dan dianggap sebagai gerakan separatis adalah gerakan yang berpusat di Provinsi Aceh dan menamakan diri dengan sebutan Gerakan Aceh Merdeka (GAM) yang kemudian mengalami konflik dengan pemerintah pusat Indonesia.

GAM pada masa Orde Baru dideklarasikan oleh Hasan Tiro pada 4 Desember 1976 yang. Konflik yang terjadi antara GAM dengan pemerintah pusat memang terjadi cukup lama, dalam hal ini pemerintah pusat mengupayakan berbagai cara untuk menyelesaikan konflik ini, baik dengan cara militer maupun dengan cara berunding atau diplomasi. Dalam perkembangannya, terutama sejak 1970-an hingga 1990-an, wilayah Aceh terus mengalami pergolakan dengan berbagai permasalah yang dihadapinya. 
Fenomena GAM yang muncul sebelum operasi jaring merah atau lebih dikenal dengan akronim DOM (Daerah Operasi Militer) pada Juli 1990 kemudian muncul kembali pasca DOM 1998 menunjukkan bahwa permasalah Aceh memang belum selesai. Eskalasi Masalah bahkan nampak di tahun-tahun terakhir, terutama karena kemunculan Anggota Gerakan Aceh Merdeka (AGAM) sebagai sayap militer GAM yang melakukan perjuangan melalui gerakan bersenjata yang pasti militeristik dan represif (Djali, 2002).

Latar belakang munculnya GAM adalah adanya ketidakpuasan rakyat Aceh terhadap pemerintah pusat yang dianggap berlaku tidak adil terhadap rakyat Aceh dalam segala aspek kehidupan, terutama dalam bidang ekonomi. Sumber daya alam Aceh dieksploitasi secara besar-besaran namun tidak ada pembagian yang proporsional antara pemerintah pusat dengan pemerintah provinsi Aceh, tentunya hal ini menyebabkan ketimpangan pembangunan antara daerah dan pusat, fenomena ini seolah-olah menandakan pemerintah pilih kasih dalam hal pembangunan, lebih mengutamakan pembangunan di Pusat daripada di daerah-daerah terjauh dan terluar. Maka dari itu, sumber daya alam Aceh yang melimpah tidak dapat dijadikan jaminan untuk membuat hidup rakyat Aceh lebih sejahtera.

Pemberontakan GAM ini juga dibangun dengan landasan ideologi nasionalis ke-Aceh-an yang dibangun oleh Hasan Tiro. Keyakinan Hasan Tiro dengan sejarah kejayaan Aceh di masa lampau untuk berdiri sendiri tanpa harus bergantung pada pemerintah pusat (Nasruddin, 2014). Aceh bersimbah darah bukanlah omong kosong semata, sejak 1873 Aceh belum merasakan kedamaian yang utuh.

Harapan sebagian besar rakyat Indonesia masih terus menginginkan Aceh tetap berada dalam ikatan Negara Kesatuan Republik Indonesia. Tengku Hasan Tiro dalam (Syafiie \& Azhari, 2009) mengatakan bahwa :

“... Indonesia adalah satu bangsa dimana ratap tangis satu golongan menjadi tertawaan golongan lain; di mana orang-orang yang dianggap pahlawan oleh satu golongan dianggap penghianat oleh golongan lainnya; di mana kekejaman terhadap satu golongan dipandang keadilan oleh golongan lain; "solidaritas nasional" hanya ada di bibir dan di poster-poster saja...”

Pernyataan Tengku Hasan Tiro bukan hanya sebatas ucap saja, tidak bisa diabaikan juga kebenarannya, tetapi juga dapat di generalisasi kebenarannya. Masalahnya adalah selama Indonesia merdeka hampir tidak pernah diperoleh kebebasan untuk mengakses informasi yang benar. Kebenaran adalah apa yang dikatakan oleh pemerintah, selain itu tidak ada kebenaran lagi. Penyebaran informasi yang bertentangan dengan apa yang di informasikan oleh pemerintah bukan hanya dikatakan sebagai penyebar informasi salah atau tukang fitnah, tetapi penyebar informasi juga akan dikatakan sebagai pemberontak atau kaum ekstrimis yang harus ditangkap. Menulis kebenaran yang tidak sesuai dengan kemauan pemerintah adalah pelanggaran, sebagai contoh buku yang ditulis oleh Tengku Hasan Tiro baru bisa diakses dan dibaca oleh rakyat Indonesia baru dimulai pada tahun 1999, padahal buku itu sudah ada sejak 1956.

Aceh adalah potret buram berbagai ketidakadilan dan pelanggaran HAM yang cukup parah dalam sejarah Indonesia. Berbagai tindak kekerasan yamg mengatasnamakan berbagai operasi dan misi dari berbagai pihak yang berkompetisi memperebutkan berbagai hal, baik dari segi politik, ekonomi, budaya dan ke-nasionalisme-an yang pada dasarnya bisa dicapai dengan pendekatan kultural dan dialogal telah terjadi sejak awal Indonesia merdeka. Pada dasarnya, konflik Aceh merupakan dasar dari akumulasi ketidakadilan dan peristiwaperistiwa ideologi-politik yang telah terjadi sejak awal kemerdekaan sampai orde sekarang ini (Adan, 2003).

Pemerintah pusat tidak tinggal diam dalam menyikapi konflik ini. Berbagai cara telah dilakukan untuk menyelesaikan konflik ini, konflik yang berkepanjangan juga tentunya berpengaruh pada stabililitas keamanan nasional. Jalur yang ditempuh pemerintah dalam menangani konflik ini adalah melalui jalur kekerasan dengan menempatkan kekuatan militer di Aceh untuk meminimalisir pergerakan GAM dan menumpas akar gerakan tersebut, cara lain yang ditempuh adalah melalui pendekatan politik.

Pendekatan politik yang ditempuh oleh pemerintah untuk meredam gejolak yang ada di Aceh adalah dengan menempatkan pejabat-pejabat baik sipil maupun militer untuk menduduki posisi-posisi strategis di wilayah Aceh. Operasi ini kemudian memuluskan jalan bagi operasi bersenjata di Aceh yang kemudian dikenal dengan operasi DOM (Daerah Operasi Militer) selama sepuluh tahun. Dari operasi inilah kemudian muncul pelanggaran HAM berat dan menyisakan rasa sakit hati yang mendalam di negeri yang tidak pernah menuai rasa aman itu (Adan, 2003).

Upaya pemerintah dalam menyelesaikan konflik melalui jalur militer mengalami kegagalan, hal ini disebabkan oleh perlawanan kembali yang dilakukan oleh GAM. Bukanlah suatu hal yang mudah untuk menundukkan masyarakat Aceh maupun gerakan-gerakannya dengan jalan militer, rakyat Aceh memiliki semangat perang fisabilillah untuk memukul mundur lawannya, rakyat Aceh juga dikenal sebagai rakyat yang pantang menyerah dalam mempertahankan apa yang menurut mereka benar. Apabila dilakukan flashback tentang bagaimana rakyat Aceh mampu mempertahankan wilayahnya terhadap serbuan-serbuan kaum penjajah, kita dapat melihat bagaimana gigihnya rakyat Aceh dan kemudian Aceh menjadi provinsi yang paling akhir jatuh ke tangan kolonial Belanda.

Tidak heran Aceh mendapat sorotan dunia Internasional perihal perjuangan rakyatnya mempertahankan kedaulatan dan marwah rakyat Aceh sendiri. Pemerintah Indonesia kemudian menyadari bahwa penyelesaian konflik melalui jalan militer dalam mengatasi permasalahan konflik antara GAM dengan pemerintah pusat tidak efektif, maka jalur lain yang ditempuh oleh pemerintah adalah dengan melakukan dialog dengan mengunakan pendekatan-pendekatan kepada rakyat Aceh dan petinggi-petinggi GAM. Cara baru yang ditawarkan oleh pemerintah tersebut setidaknya memunculkan harapan baru ditemukannya sebuah penyelesaian konflik yang tepat bagi semua pihak. 
Penyelesaian konflik dengan cara baru ini memanfaatkan pihak ketiga yang disebut sebagai mediator, hal ini ditempuh sebagai upaya untuk mencari kesepakatan politik kedua belah pihak, cara ini dianggap menjadi lebih elegan untuk pemerintah pusat maupun masyarakat Aceh sendiri. Djumala (2013, hlm. 23) menjelaskan bahwa :

"Ketersediaan pusat untuk berdialog dan berunding merupakan penghargaan atas martabat rakyat Aceh. Cara-cara penyelesaian konflik secara bermartabat inilah kiranya yang memungkinkan Aceh bersedia untuk berunding, sehingga konflik dapat diselesaikan".

Apabila dilihat sekilas bagaimana kebijakan yang diterapkan pada masa Orde Baru, Orde Lama, dan Reformasi dimana seringnya terjadi pergantian presiden, tentunya hal ini juga akan berpengaruh terhadap kebijakan penanganan konflik Aceh. Namun, segala upaya yang telah dilakukan oleh pemerintah pusat seringkali mengalami kegagalan dan ditemukan ketidak sesuaian antara keinginan, harapan dengan kenyataan dari kedua belah pihak. Penanganan konflik yang dilakukan oleh pemerintah pusat pada masa Orde Lama, Orde Baru dan penanganan konflik oleh pusat pada masa Reformasi terlihat perbedaan yang cukup signifikan. Perubahan pola penanganan konflik Aceh pasca Orde Baru yaitu setelah lengsernya presiden Soeharto mulai memperlihatkan kebijakan yang diambil oleh pemerintah pusat dalam penanganan konflik, Djumala (2013, hlm. 23) menjelaskan bahwa :

"Panglima ABRI (Angkatan Bersenjata Republik Indonesia) Jenderal Wiranto berusaha untuk meraih kembali kepercayaan publik dengan mencabut daerah operasi militer (DOM) di Aceh 7 Agustus 1998. Di samping pencabutan status DOM Jenderal Wiranto juga meminta maaf atas perilaku individu TNI semasa DOM. Tidak hanya Wiranto, Habibie pun ketika berkunjung ke Aceh pada Maret 1999 juga meminta maaf atas apa yang telah dilakukan oleh aparat keamanan".

Penghapusan status Aceh sebagai Daerah Operasi Militer oleh Panglima TNI Wiranto memberikan harapan baru kepada rakyat Aceh. Pemerintah pusat kemudian berusaha untuk memperbaiki hubungan baik dengan rakyat Aceh berikut petinggi-petingginya dan menyudahi konflik yang sudah berkepanjangan, cara penyelesaian konflik secara damai ini kemudian mendapatkan bantuan dari suatu lembaga yang berperan sebagai mediator atau pihak ketiga. Kesepakatan untuk mendatangkan mediator merupakan hasil kesepakatan bersama antara Pemerintah Indonesia dengan GAM, hal ini merupakan salah satu alternatif solusi yang lebih elegan bagi kedua pihak. Mediator yang didatangkan adalah

Penulis memiliki ketertarikan dalam mengkaji faktorfaktor penyebab dipilihnya Crisis Management Initiative dalam upaya penyelesaian konflik di Aceh. Hal menarik di atas kemudian dapat dirinci sebagai pertanyaan penelitian yang akan dikaji dalam riset ini, antara lain: Pengaruh GAM terhadap konflik Aceh dan alasan mengapa kedua belah pihak memilih Crisis Management Initiative sebagai mediator dalam penyelesaian konflik, bagaimana dampak dari hasil perundingan tersebut bagi masyarakat Aceh.

\section{METODE PENELITIAN}

Dalam menulis penelitian ini, penulis menggunakan metode penelitian sejarah atau historis dengan menggunakan studi literatur sebagai teknik penelitiannya. Metode penelitian sejarah menurut Sjamsuddin (2012) terdiri dari heuristik, kritik, dan historiografi. Menurut Sartono Kartodirdjo (dalam Sjamsuddin, 2012) metode dan metodologi merupakan fase yang berbeda untuk tugas yang sama. Metode merupakan cara untuk memperoleh pengetahuan, sementara metodologi merupakan cara bagaimana harus mengetahui.

Selain itu, menurut Hilbish (dalam Abdurahman, 2007: 53) yang dimaksud dengan metode penelitian sejarah ialah suatu penyelidikan untuk menemukan fakta-fakta yang berguna untuk menghasilkan produk baru, memecahkan suatu masalah, ataupun untuk memperkuat atau menolak suatu teori. Pengertian lain yang disampaikan oleh Gilbert J Garraghan (Abdurahman, 2007) mengemukakan mengenai metode penelitian sejarah ialah seperangkat pedoman atau prinsip sistematis untuk mengumpulkan sumber-sumber sejarah secara efektif, memverifikasi dan mengajukan sintesis dari hasil-hasil yang dicapai dalam bentuk tertulis.

\section{HASIL PENELITIAN DAN PEMBAHASAN}

Dalam peta konflik dan damai di Aceh, GAM merupakan entitas dan aktor penting yang layak diperhitungkan pengaruhnya. Keterlibatannya secara langsung dalam konflik bersenjata di Aceh lebih dari dua dekade menunjukkan bahwa kelompok ini serius memperjuangkan cita-citanya melepaskan Aceh dari bingkai Negara Kesatuan Republik Indonesia. Begitu pula keterlibatannya dalam proses damai yang dirintis sejak akhir 1999 memperlihatkan bahwa GAM memiliki nilai tawar tinggi dalam menyelesaikan konflik yang sudah berlangsung lama itu (Sahlan, 2013).

Konflik antara GAM dan Pemerintah Indonesia sudah terjadi dua kali sejak dibentuk Negara Kesatuan Republik Indonesia (NKRI), yaitu konflik DI/TII pada tahun 19531962 dan konflik GAM pada tahun 1976-2005. Kedua konflik tersebut memiliki perbedaan tujuan, konflik pertama bertujuan untuk memperoleh otonomi sedangkan konflik kedua bertujuan untuk memperoleh kemerdekaan. Pada akhirnya, kedua konflik tersebut dapat diselesaikan melalui negosiasi yang menghasilkan satu kesepahaman dan kesepakatan damai (Zainal, 2016).

GAM merupakan bentuk perlawanan dari rakyat Aceh terhadap pemerintah Indonesia untuk memperoleh kemerdekaannya dari NKRI. Pemerintah Indonesia menyikapinya sebagai gerakan pengacau stabilitas keamanan atau pemberontak dan dilabeli sebagai Gerakan Pengacau Keamanan (GPK), Gerakan Pengacau Liar (GPLK) atau Gerakan Pengacau Liar Hasan Tiro (GPLHT). GAM mucul karena adanya perasaan sakit hati terhadap pemerintah 
Indonesia yang dianggap menghianati identitas masyarakat Aceh yang sebelumnya pernah dituntut pada era DI/TII serta penguasaan terhadap sumber daya alam Aceh oleh Pemerintah Indonesia dan pendistribusiannya kepada daerah Aceh dilakukan secara tidak adil.

Eksistensi GAM pada awal pembentukannya masih lemah karena tidak sebanding dengan kekuatan pemerintah RI sehingga GAM sangat mudah untuk dilumpuhkan oleh pemerintah melalui pendekatan militer. Langkah GAM dalam melakukan pemberontakan pada masa itu merupakan kesalahan besar yang pernah dilakukan oleh GAM karena memilih waktu yang kurang tepat yaitu disaat pemerintah Orde Baru berada dalam kondisi yang sangat stabil, baik dalam bidang politik, ekonomi bahkan pembangunan (Sahlan, 2013). Stabilitas politik pembangunan masa Orde Baru menyebabkan GAM sulit bergerak dan berkembang di tengah-tengah masyarakat.

Perlawanan GAM pada fase pertama hanya efektif berjalan selama dua tahun. Pihak keamanan pemerintah berhasil mempersempit ruang gerak dan melumpuhkan gerakan GAM dengan pendekatan militeristik, selanjutnya hal inilah yang menyebabkan sebagian pemimpin GAM terbunuh, ditangkap, dan ada sebagian yang berhasil melarikan diri ke luar negeri. Respon pemerintah terhadap kebangkitan GAM pada fase kedua berbeda dengan fase pertama, fase kedua kali ini ditandai dengan pulangnya ratusan pemuda yang telah mendapat pelatihan militer di Libya. Pada fase ini pemerintah melakukan dua pendekatan sekaligus, yaitu pendekatan militer dan pendekatan politik.

Kekuatan militer yang dimiliki Pemerintah RI untuk mendukung pendekatan militer dalam menumpas GAM jauh lebih besar dibandingkan dengan kekuatan GAM. Perbandingan jumlah anggota dan kekuatan militer antara pasukan GAM dengan kekuatan militer Pemerintah Indonesia tidak sebanding dan sudah cukup bagi pemerintah Indonesia untuk menumpas GAM yang jumlahnya masih sangat kecil, tetapi pemerintah tetap mengupayakan pendekatan politis. Pemerintah Indonesia melalui pendekatan ini mendapatkan dua keuntungan sekaligus, yaitu selain membantu dan meringankan langkah militer menumpas GAM melalui seruan tokoh masyarakat supaya GAM turun gunung, langkah ini juga dilancarkan demi mendapatkan legitimasi politis terhadap pendekatan militeristik.

Perjuangan GAM memperoleh simpati dari kalangan masyarakat sipil, terutama dari mereka yang mendukung penegakan HAM, mereka menganggap bahwa apa yang dilakukan oleh aparat militer bukan hanya pelanggaran HAM ringan, tetapi hingga berupa tindakan kejahatan penghabisan etnis (the crimes ofgenocide) (Gade, 2001). Sikap politikSoeharto dan TNI yang sangat keras terhadap GAM dirasionalisasi dengan semboyan "NKRI Harga Mati" dan tidak ada ideologi selain Pancasila di Indonesia (Djumala, 2013). Operasi militer yang terjadi selama kurun waktu 1989-1999 berhasil menekan GAM hingga ke posisi terlemah. Operasi ini pun berakhir pasca runtuhnya rezim Orde Baru oleh Gerakan Reformasi akibat adanya krisis moneter. Krisis moneter yang melanda Asia juga berdampak terhadap Indonesia, salah satunya krisis di bidang ekonomi menyebabkan kesulitan dalam pengadaan persenjataan dan gaji bagi petugas TNI yang bertugas di daerah konflik. Pasca Soeharto lengser dari jabatannya sebagai presiden RI, masuklah Indonesia ke rezim baru yang dipimpin oleh B.J Habibie, pada masa awal pemerintahannya muncul gerakan massa yang menolak keterlibatan militer hingga menimbulkan sentimen "Anti-Jakarta".

Pendekatan militer yang dilakukan oleh Pemerintah Indonesia dan di dukung oleh tokoh masyarakat dan ulama Aceh dalam memberantas GAM ternyata telah memberikan dampak buruk bagi masyarakat sipil di Aceh. Sejumlah kasus pelanggaran HAM telah terjadi selama sepuluh tahun pasca penerapan Operasi Jaring Merah di Aceh. Kasus ini baru diketahui ketika rezim Orde Baru lengser digantikan oleh rezim Reformasi. Hasil investigasi yang dilakukan oleh lembaga pemantau HAM ditemukan telah terjadi 7.727 kasus pelanggaran HAM di Aceh selama diterapkannya Operasi Jaring Merah (1989-1998). Angka tersebut cukup fantastis dan mengejutkan semua pihak sehingga sejumlah institusi lain pun ikut melakukan investigasi dan verifikasi terhadap bukti awal yang ditemukan sebelumnya, data ini diperoleh dari hasil investigasi kolektif Forum Peduli HAM (FPHAM) pada tahun 1998-1999.

Bentuk dari pelanggaran HAM yang dilakukan oleh pihak militer Indonesia yang terjadi di Aceh cukup beragam seperti pembunuhan, penyiksaan atau penganiayaan baik secara fisik atau mental, penangkapan dan penahanan secara sewenangwenang, perkosaan dan kekerasan seksual, penghilangan paksa dan pembakaran rumah-rumah penduduk dan fasilitas umum. Pola ini dinilai tidak sekedar merupakan pelanggaran HAM biasa melainkan telah menjadi suatu tindakan kejahatan terhadap kemanusiaan (crimes against humanity). Bahkan lebih jauh lagi adanya tindakan kejahatan berupa pembunuhan secara besar-besaran (the crimes genocides) (Ismail dkk, 2001).

Berdasarkan laporan dari amnesti internasional dalam Kirsten \& Schulze (2004: 5) dijelaskan mengenai upaya Pemerintah Indonesia dalam memberantas GAM :

In an effort to undercut the civilian support base of the guerrilla resistance, Indonesian forces carried out armed raids and house-to-house searches in suspected rebel areas. The houses of villagers suspected of providing shelter or support to the rebels were burned to the ground. The wives or daughters of some suspected rebels were detained as hostages and some were raped. Anyone suspected of contact with Aceh Merdeka was vulnerable to arbitrary arrest and detention, torture, "disappearance" or summary execution. (Dalam upaya untuk melemahkan dukungan basis sipil terhadap perlawanan gerilya, Pasukan Indonesia melakukan serangan bersenjata dan pencarian dari rumah ke rumah di daerah yang dicurigai sebagai wilayah tempat tinggal para pemberontak. Rumah-rumah penduduk yang dicurigai menyediakan tempat tinggal atau memberikan dukungan kepada para pemberontak akan dibakar hingga rata menjadi tanah. Istri atau putri dari beberapa tersangka pemberontak ditahan sebagai sandera dan beberapa lainnya diperkosa. Siapapun yang diduga kontak dengan Aceh Merdeka rentan terhadap

HISTORIA: Jurnal Pendidik dan Peneliti Sejarah, p-issn:2620-4789 | e-issn:2615-7993 
penangkapan dan penahanan sewenang-wenang, penyiksaan, "penghilangan" atau eksekusi ringkasan).

Tuntutan terhadap pelanggaran HAM yang dilakukan TNI semakin terbuka dan meluas di kalangan masyarakat sipil, baik di Aceh maupun di luar Aceh, hal ini mendorong Panglima Angkatan Bersenjata Republik Indonesia (ABRI) Jenderal Wiranto dan Presiden Habibie untuk mencabut status DOM di Aceh pada tanggal 7 Agustus 1998 dan meminta maaf atas perilaku kekerasan yang dilakukan oleh personil TNI (Zainal, 2016). Meskipun pemerintah Indonesia telah mencabut status DOM dan meminta maaf kepada rakyat Aceh, pendekatan militer dengan nama yang berbeda masih diberlakukan di Aceh seperti Operasi Wibawa (Bermula 2 Januari 1999), Operasi Sadar Rencong I (Mei 1999-Januari 2000), Operasi Sadar Rencong II (Februari 2000-Mei 2000), Operasi Sadar Rencong III (Juni 2000-Juni 2001) dan Operasi Cinta Damai (2001-2002). Operasi militer tersebut tidak membuat keamanan di Aceh membaik, pembunuhan, penyiksaan, penculikan dan pemerkosaan semakin parah (Zainal, 2016).

Akibat dari operasi militer yang masih berlangsung, gelombang pengungsian pun semakin meningkat, padahal ketika itu juga dilaksanakan strategi pemulihan ekonomi dan kesejahteraan bagi rakyat Aceh (Prosperity approacch). Pemerintah memberikan amnesti kepada tahanan politik GAM, bantuan kepada anak yatim dan janda korban konflik serta kesempatan kerja kepada anak bekas kombatan GAM. Selain itu, keistimewaan lagi bagi Aceh di Bidang agama, budaya dan pendidikan ditegaskan kembali melalui UU No.44 tahun 1999 (Marzuki \& Warsidi, 2011). Meskipun demikian, pelanggaran HAM berupa kekerasan yang dilakukan oleh militer Indonesia tetap masih terjadi. Akibatnya, pelanggaran HAM terus terjadi tanpa pengadilan untuk mewujudkan keadilan dan penghentian kekerasan.

Pelanggaran HAM yang kembali terjadi menjadi alasan diadakannya kongres oleh mahasiswa dan pemuda Aceh yang dinamakan Kongres Mahasiswa dan Pemuda Aceh Serantau (KOMPAS) pada tahun 1999 dengan hasil menetapkan referendum sebagai cara penyelesaian konflik yang terbaik bagi Aceh. Pilihan yang diusulkan adalah merdeka atau tetap bergabung dengan Indoneisa. Sejak saat itu, Sentral Informasi Referendum Aceh (SIRA) yang dibentuk untuk dijadikan sebagai wadah sosialisasi kepada masyarakat secara proaktif menyampaikan agenda terkait kepada seluruh masyarakat Aceh.

Hasil dari kongres KOMPAS tersebut adalah hadirnya jutaan masyarakat Aceh dalam sidang rakyat untuk referendum pada tanggal 8 November 1999. Menurut Nurhasyim (Zainal, 2016) realitas politik demikian direspon baik oleh panitia khusus dari Dewan Perwakilan Rakyat (DPR) RI untuk permasalahan Aceh. Pada tanggal 16 Desember 1999 mereka meminta pemerintah Indonesia segera mengintensifkan dialog dengan semua elemen masyarakat Aceh, bahkan dengan lembaga legislatif, eksekutif dan yudikatif Aceh agar mendapat kesempatan mengenai langkah-langkah penyelesaian konflik secara komprehensif secepat mungkin. Hal inilah kemudian yang menjadi permulaan dari negosiasi (soft power) dalam penyelesaian konflik yang kemudian ditindak lanjuti oleh pemerintahan berikutnya.

Pemerintah Indonesia menyadari bahwa pendekatan militer tidak lagi efektif untuk melumpuhkan GAM. Presiden berikutnya, yaitu Abdurrahman Wahid pada tahun 1999 mengganti pendekatan militer menjadi pendekatan dialog (negosiasi) sekaligus berusaha menyelesaikan konflik GAM secara eksternal dengan melibatkan pihak ketiga, yaitu dengan melibatkan sebuah organisasi non-pemerintah atau lembaga swadaya internasional. Peran pihak ketiga sangat tepat dilaksanakan dalam menyelesaikan konflik baik internal maupun internasional. Dalam konflik internal, apabila negosiasi langsung antar pihak yang bersengketa menemui jalan buntu, maka jasa pihak ketiga dapat digunakan sebagai alternatif penyelesaian konflik secara damai dan bermartabat. Menurut Vernon (Iqbal, 2014) Pihak ketiga dalam menyelesaikan konflik internal boleh dilakukan oleh pemerintah, organisasi internasional atau individu-individu yang ditunjuk khusus.

NGO adalah organisasi non pemerintah yang mampu menyelesaikan konflik dengan cara berperan sebagai penengah dalam menjembatani pihak-pihak yang bertikai dalam mencari suatu kesepakatan bagi pihak-pihak yang bersengketa. John Burton dan Frank Dukes (Iqbal, 2014) menjelaskan bahwa ada dua fokus kajian NGO dalam menyelesaikan suatu konflik, diantaranya : (1) Menjelaskan gejala konflik dan kekerasan di dalam masyarakat dan masyarakat dunia guna menemukan pendekatan konstruktif untuk memecahkannya; (2) untuk menemukan prinsip-prinsip dari proses dan kebijakan yang diturunkan dari suatu penjelasan mengenai konflik.

Era pemerintahan SBY-JK kembali melakukan negosiasi dengan GAM dengan melibatkan Crisis Management Initiative (CMI) sebagai pihak ketiga atau mediator. Pemerintah Indonesia saat itu yakin bahwa pendekatan militer memang dapat melemahkan kekuatan GAM, tetapi tidak dapat menyelesakan permasalahan konflik Aceh secara tuntas dan permanen sehingga muncul perpaduan kebijakan di pemerintah pusat yang mampu mengatasi oposisi politik yang tidak menyukai pendekatan negosiasi. Pemerintahan SBYJK mengambil langkah yang lebih berani lagi dalam upaya penyelesaian konflik ini, yaitu dengan memberikan otonomi yang lebih luas lagi kepada Aceh dengan menambahkan keistimewaan di bidang politik (Djumala, 2013). Hal tersebut diwujudkan dengan membentuk tim ad hoc yang terdiri dari Hamid Awaluddin (Menteri Keadilan dan Hak Asasi Manusia), Sofyan Jalil (Menteri Komunikasi) dan Farid Husain (Direktur Jenderal di Departemen Kesehatan) untuk menjalankan negosiasi dengan GAM. Tim GAM terdiri dari anggota kepemimpinan yang diangkat di pengasingan yang dipimpin oleh Perdana Menteri Pemerintahan Negara Aceh Malik Mahmud dan disertai oleh Menteri Luar Negeri GAM, Dr Zaini Abdullah, juru bicara Bakhtiar Abdullah dan pejabat politik Nur Djuli dan Nurdin Abdul Rahman.

GAM menyetujui negosiasi yang diusulkan oleh Pemerintah Indonesia dengan CMI sebagai mediatornya 
karena Pemerintah Indonesia lebih fleksibel dalam menyikapi tuntutan GAM. CMI juga menganjurkan Pemerintah Indonesia dan GAM bersikap fleksibel dan menurunkan tuntutan masing-masing. Pemerintah Indonesia menawarkan otonomi yang lebih luas daripada sebelumnya dan GAM menurunkan tuntutannya untuk merdeka. Selanjutnya, Pemerintah Indonesia juga diminta untuk tidak menangkap lagi anggotaangota GAM ketika perundingan sedang berlangsung seperti yang pernah terjadi di masa pemerintahan sebelumnya.

Pihak ketiga juga berperan sebagai lembaga pengawas dan pemantau penerapan hasil perundingan, merancang strategi untuk mengintegrasikan mantan kombatan GAM ke dalam masyarakat Aceh dan memberikan tawaran baru kepada pihak GAM, pihak GAM juga diminta untuk tidak menuntut kemerdekaan karena belum mendapat sokongan dari dunia internasional dan sebagai syarat untuk memperoleh bantuan dalam menyelesaikan konflik Aceh. Perundingan harus didiskusikan secara komprehensif, utuh dan bertahap dengan batas waktu perundingan yang harus diakhiri pada bulan Juli 2005 .

Untuk mewujudkan rasa saling percaya antara kedua belah pihak, terutama kepercayaan GAM kepada pemerintah Indonesia, negosiasi di luar meja perundingan juga resmi dilakukan dengan elemen-elemen masyarakat yang memiliki hubungan dekat dengan GAM. Mereka diharapkan dapat mempengaruhi perubahan pikiran dari tokoh-tokoh GAM terhadap pemerintah Indonesia, baik tokoh GAM yang di Aceh maupun di luar negeri.

Faktor lain yang turut memberikan pengaruh terhadap pelaksanaan perjanjian damai ini adalah musibah Tsunami yang terjadi pada 26 Desember 2004 di kawasan pesisir utara Aceh. Musibah ini menewaskan kurang lebih 150.000 jiwa dan merusak semua sektor kehidupan rakyat Aceh. Kehancuran ini mendapat sorotan internasional dan mendorong upaya bantuan kemanusiaan secara besar-besaran ke Aceh. Mengirimkan bantuan ke wilayah konflik bukanlah hal yang mudah, para relawan juga khawatir mengenai kondusitifas di wilayah tersebut. Tsunami menjadi pukulan yang cukup keras bagi kedua belah pihak, baik GAM maupun pemerintah Indonesia, pada akhirnya hal itu menjadi katalis yang membawa kedua belah pihak ke meja untuk melakukan perjanjian perdamaian dan memfasilitasi proses pemulihan Aceh (Lusia, 2010).

CMI dipilih sebagai mediator dalam penyelesaian konflik GAM-RI dikarenakan CMI adalah NGO internasional yang bergerak di bidang resolusi konflik dan sudah berpengalaman sejak tahun 2000 dan berpusat di kota Helsinki, Finlandia. Selain itu, posisi perundingan yang akan dilakukan juga berdekatan dengan tempat petinggi-petinggi GAM yang berada di Swedia.. CMI dan pimpinannya, Presiden Martti Ahtisaari, diminta secara resmi untuk memfasilitasi dialog antara Pemerintah Republik Indonesia dan GAM dengan tujuan untuk mengakhiri konflik bersenjata.

Menurut Christensen (Lusia, 2010) alasan kenapa memilih Presiden Ahtisaari, karena setelah CoHA dan HDC, harus ada institusi dan organisasi yang lebih tinggi dari HDC dan harus ada orang yang menjadi mediator kehormatan di dunia daripada yang lebih dulu. Presiden Ahtisaari, sudah memiliki institusi sendiri, memiliki kantor CMI, kemudian tingkatnya lebih tinggi dari organisasi yang lebih dulu. Selain itu, Martti Ahtisaari juga memiliki hubungan langsung dengan Kofi Anan (Sekjen PBB), beliau kenal baik sekali dengan pimpinan Uni Eropa (Nurhasim, 2008). Tempat yang dipilih untuk melakukan perundingan berasa di kota Helsinki, Finlandia tepatnya di Kőnigstedt Manor yang biasanya dijadikan tempat untuk menerima tamu negara oleh Pemerintah Finlandia. Perundingan ini dilaksanakan mulai dari bulan Januari 2005 hingga Agustus 2005 yang ditandai dengan penandatanganan MoU Helsinki oleh GAM dan Pemerintah Indonesia. Perjanjian ini terdiri dari enam pokok bahasan berkenaan dengan Penyelenggaraan Pemerintah di Aceh Undang-undang tentang penyelenggaraan Pemerintahan di Aceh, Partisipasi Politik, Ekonomi, Peraturan Perundangundangan, Hak Asasi Manusia, Amnesti dan reintegrasi ke dalam masyarakat, Pengaturan Keamanan, Pembentukan Misi Monitoring Aceh dan Penyelesaian perselisihan.

Keberhasilan dari penandatanganan nota kesepahaman ini ditempuh dengan cara melakukan dialog secara berkelanjutan. Dialog pada putaran pertama dimana pertama kali kedua belah pihak bertemu muka setelah bulan Mei 2003 berlangsung mulai tanggal 27 hingga 29 Januari 2005 di Helsinki. Dialog putaran kedua terjadi dari tanggal 21 sampai 23 Februari, putaran ketiga dari tanggal 12 sampai 16 April, dan putaran keempat dari tanggal 26 sampai 31 Mei 2005. Antara pembicaraan putaran keempat dan kelima, CMI menyiapkan sebuah draf Memorandum of Understanding (Nota Kesepahaman) yang meletakkan dasar mengenai pembahasan untuk dialog putaran kelima. Perundingan putaran kelima diselenggarakan dari tanggal 12 sampai 17 Juli, dan akhirnya MoU ditandatangani di Helsinki pada tanggal 15 Agustus 2005. Putaran pertama diselenggarakan pada 27-29 Januari 2005, Martti Ahtisaari selaku pimpinan CMI menginstruksikan kedua belah pihak untuk melakukan diskusi dan tawar menawar kebijakan yang akan ditempuh demi penyelesaian konflik Aceh secara rasional dan dapat diimplementasikan.

Perundingan tahap kedua diselenggarakan pada 2123 Februari 2005 diisi dengan pembahasan mengenai halhal substansial mengenai otonomi khusus dan pembahasan tentang self-government. Mediator selalu berusaha untuk menjaga kekondusifan proses perundingan, apabila mulai terjadi ketegangan antar pihak yang berunding maka mediator mengingatkan untuk kembali kondusif dan fokus terhadap penyelesaian permasalahan.

Perundingan tahap ketiga diadakan pada 12-16 April 2005. Pada putaran ini delegasi dari GAM dan Pemerintah Indonesia lebih banyak bertemu langsung tanpa perantara mediator. Perundingan tahap keempat dilaksanakan pada tanggal 26-31 Mei 2005 dan membahas partisipasi GAM dalam politik, amnesti, ekonomi dan integrasi GAM ke dalam masyarakat. Selain itu, CMI juga memfasilitasi kedua belah pihak unuk bertemu dengan Pieter Feith selaku direktur pemantau keamanan yang nantinya akan turut andil dalam proses perdamaian di Aceh. 
Perundingan terakhir yang berlangsung pada 12-17 Juli 2005 membicarakan masalah HAM dan dilanjutkan dengan pengaturan keamanan. CMI memfasilitasi pertemuan antara GAM dan Pemerintah Indonesia dengan Uni Eropa. CMI mengajak Uni Eropa untuk terlibat secara aktif. Keterlibatan Uni Eropa tidak hanya sebatas keterlibatan dalam komitmen pendanaan saja, tetapi juga komitmen politik. Salah satu bentuk dukungan yang diberikan oleh Uni Eropa pasca penandatanganan nota kesepahaman adalah dengan mengirimkan Initial Monitoring Presence (IMP) atau keberadaan monitoring awal yang dikirim langsung ke Aceh sebelum penempatan Aceh Monitoring Mission (AMM). Selanjutnya, Uni Eropa dan negara-negara ASEAN mengirimkan AMM untuk memantau implementasi MoU dimulai sejak 15 September 2005.

Setelah perundingan tahap kelima ini selesai, akhirnya penandatanganan nota kesepahaman ini dilaksanakan pada 15 Agustus 2005 di Helsinki. Isi dari nota kesepaham tersebut mengatur hal-hal berikut yang selanjutnya akan diberlakukan di Aceh :

1. Penyelenggaraan Pemerintahan di Aceh.

2. Hak Asasi Manusia.

3. Amnesti dan reintegrasi ke dalam masyarakat.

4. Pengaturan Keamanan.

5.Pembentukan Misi Monitoring Aceh.

6. Penyelesaian perselisihan.

Pasca penandatanganan perjanjian damai. Para petinggi GAM yang ada diluar negeri kembali ke Aceh dan pejuang GAM yang ada di pegunungan mulai turun dan berusaha menyatu dengan masyarakat. Aceh mulai menata kembali keadaan yang sempat hancur akibat konflik, sistem self government di Aceh mulai diberlakukan bertahap sesuai dengan isi perjanjian. Di sisi lain, CMI tetap memantau kedua belah pihak dan implementasi perjanjian damai di Aceh, sebenarnya kontrak kerjasama antara GAM dan Pemerintah Indonesia dengan CMI hanya sampai tahun 2009, akan tetapi CMI merasa perlu adanya perpanjangan kontrak karena terdapat beberapa fakta di lapangan yang tidak sesuai dengan kesepakatan yang dibuat. Oleh karena itu, CMI mengusulkan perpanjangan kontrak hingga tahun 2012 untuk memantau dan melakukan evaluasi terhadap kedua belah pihak.

Pihak pemerintah Indonesia berhasil mempertahankan Aceh untuk tetap berada dalam bingkai Negara Kesatuan Republik Indonesia dengan berbagai upaya yang telah ditempuh sebelumnya. Langkah selanjutnya yang harus ditempuh adalah untuk mengimplementasikan hasil perjanjian damai dan merawat perdamaian demi terwujudnya kestabilan nasional.

\section{SIMPULAN}

Pengaruh GAM terhadap konflik Aceh. Peneliti menganalisis bahwa GAM merupakan perwujudan dari ekspektasi yang tidak sesuai dengan realita di Aceh dan berujung konflik. organisasi ini terbentuk karena kekecewaan rakyat Aceh terhadap Presiden Soekarno yang tidak menepati janjinya dalam mengabulkan permintaan rakyat Aceh untuk memberlakukan Syariat Islam. GAM mulai muncul pada tahun 1953 dengan tujuan untuk memperjuangkan hak-hak masyarakat Aceh. Realisasi dari janji Presiden Soekarno tidak dilaksanakan, justru yang terjadi adalah kebalikan dari janji manis itu. Pemerintahan Republik Indonesia mengadakan sebuah sistem penyederhanaan administrasi pemerintahaan pada tahun 1950 yang mengakibatkan beberapa daerah di Indonesia mengalami penurunan status. Salah satu dari semua daerah yang statusnya turun yaitu Aceh, yang tadinya menjabat sebagai Daerah Istimewa, setelah operasi penyederhanaan tersebut di mulai status Aceh pun berubah menjadi daerah keresidenan yang di kuasai oleh provinsi Sumatera Utara. Penghapusan hak istimewa ini sangat berdampak terhadap perekonomian dan sistem pemerintahan di Aceh, sehingga Aceh merasa dianak tirikan.

Latar belakang dipilihnya CMI sebagai mediator dalam penyelesaian konflik antara GAM dengan pemerintah Indonesia. Peneliti dapat menganalisis alasan CMI dipilih sebagai mediator karena CMI merupakan organisasi nonpemerintahan yang berpusat di Finlandia, tepatnya di Kota Helsinki dan bergerak di bidang resolusi konflik dan serta berpengalaman sejak tahun 2000. CMI sudah pernah menangani beberapa kasus konflik yang ada di beberapa negara seperti di Afrika Selatan, Afrika Barat, Liberia, Timur Tengah, Afganistan dan lain-lain. CMI diketuai oleh seorang mantan Presiden Finlandia yang bernama Martti Ahtisaari. Beliau merupakan sosok yang sangat dikenal di kalangan negara-negara Uni Eropa, track record Martti Ahtisaari tidak perlu diragukan lagi dalam hal mediasi. Kedekatannya dengan Uni Eropa memudahkannya dalam mengusulkan bantuan dana dalam pelaksanaan mediasi agar mediasi dapat berjalan secara berkelanjutan hingga konflik di suatu negara dapat teratasi.

Proses perundingan damai. Diskusi yang dilakukan oleh semua pihak dilakukan sebanyak 13 kali pertemuan dengan 5 kali putaran. Pertama kali diskusi dimulai pada bulan Januari 2005 dan berlanjut hingga Agustus 2005, selama proses perundingan, baik pihak GAM maupun Pemerintah Indonesia saling memberikan tawaran-tawarannya dan didiskusikan secara bersama. Akhirnya perundingan pun sukses dilaksanakan dan hingga para pihak yang bertikai melakukan penandatanganan perjanjian damai atau yang lebih dikenal sebagai MoU Helsinki.

Dampak dari perjanjian damai di Aceh adalah adanya kebebasan dalam kehidupan bermasyarakat, masyarakat sipil bisa kembali bekerja, para kombatan GAM turun gunung dan kembali ke keluarga masing-masing, gencatan senjata mulai berkurang dan kehidupan masyarakat di Aceh perlahan menjadi lebih baik. Meskipun memang di masa transisi menuju perdamaian masih terdapat gencatan senjata dan tindak kekerasan, tetapi makin lama makin berkurang. Selain itu, juga berpengaruh terhadap pendistribusian bantuan untuk korban Tsunami di Aceh pada tanggal 26 Desember 2004. Dampak lainnya adalah adanya upaya untuk meningkatkan kesejahteraan masyarakat Aceh pasca konflik dan tsunami, yaitu dengan pemberian dana pendidikan, kesehatan dan pekerjaan bagi para mantan kombatan GAM. CMI masih memantau perkembangan pelaksanaan perjanjian damai di 
Aceh, harusnya kontrak dengan CMI berakhir pada tahun 2009, namun dengan beberapa pertimbangan kontrak dengan CMI diperpanjang untuk memantau implementasi dari MoU helsinki. Pada tahun 2012, kontrak dengan CMI resmi berakhir dan diharapkan konflik yang terjadi di Aceh ini juga benar-benar berakhir.

\section{REFERENSI}

Abdurahman, D. (2007). Metodologi Penelitian Sejarah. Yogyakarta: Ar-Ruzz Media.

Adan, H. Y. (2003). Tamaddun \& Sejarah: Etnografi Kekerasan di Aceh. Yogyakarta: Prismashopie Press.

Awaluddin, H. (2008). Damai di Aceh : Catatan Perdamaian RI-GAM di Helsinki. CSIS.

Djali. M. Y. (2002). Perekat Hati yang Tercabik. Banda Aceh: Ulul Arham.

Djumala, D. (2013). Soft Power untuk Aceh : Resolusi Konflik dan Politik Desentralisasi. Jakarta: PT Gramedia Pustaka Utama

Hamzah, M. (2016). Dokter Zaini Abdullah Pejuang Rakyat Aceh. Yogyakarta: Pale Media Prima.

Iqbal, M. (2014). Fenomena Kekerasan Politik di Aceh Pasca Perjanjian Helsinki. Jurnal Hubungan Internasional, Vol. 7 - No. 2 / 2014-10153-166.

Ismail, M. G. (2001). Aceh, Jakarta, Papua : Akar Permasalahan dan Alternatif Proses Penyelesaian Konflik. Jakarta: Yappika.
Lusia, H. (2010). Mediasi Yang Efektif Dalam Konflik Internal Studi Kasus : Mediasi oleh Crisis Management Initiative Dalam Proses Perdamaian Gerakan Aceh Merdeka Dan Pemerintah Republik Indonesia.[Tesis] Jakarta: Universitas Indonesia.

Nasruddin. (2014). Pengaruh Konflik GAM-RI Terhadap Kehidupan Beragama, Sosial dan Politik Rakyat Aceh (1976-2005).[Skripsi]. Yogyakarta: UIN Sunan Kalijaga.

Nurhasim, M. (2008). Konflik dan Integrasi Politik Gerakan Aceh Merdeka, Kajian tentang Konsensus Normatif antara RI-GAM dalam Perundingan Helsinki. Yogyakarta: Pustaka Pelajar.

Sahlan, M. (2013). Mediasi Konflik Aceh : Belajar dari Pengalaman HDC di Aceh. Banda Aceh : Ar-Raniry Press.

Schulze, K. E. (2004). The Free Aceh Movement (GAM): Anatomy of a Separatist Organization. Washington DC: East-West Center Washington.

Sjamsuddin, H. (2012). Metodologi Sejarah. Yogyakarta: Ombak.

Syafiie, Inu K \& Azhari. (2009). Sistem Politik Indonesia. PT Refika Aditama : Bandung.

Zainal, S. (2016). Transformasi Konflik Aceh dan Relasi SosialPolitik di Era Desentralisasi. Jurnal Sosiologi, Vol. 21 No. 1 hlm. 81-108. 